\title{
The contribution of ecology to science*
}

\author{
Wkład ekologii w naukę
}

\author{
Bernard Hałaczek \\ Institute of Ecology and Bioethics, Cardinal Stefan Wyszyński University in Warsaw, Poland
}

\begin{abstract}
This article is an analysis of the creative function of ecology in terms of knowledge. That is why the ecology asks "how should be". In this way, it faces a true human problem.
\end{abstract}

Keywords: ecology, science, traditional concept of science, criticism of science

Streszczenie: Niniejszy artykuł jest analizą twórczej funkcji ekologii w kategoriach nauki. Jako taka ekologia pyta "jak być powinno". W ten sposób staje wobec rzeczywistych problemów ludzkich.

Słowa kluczowe: ekologia, nauka, tradycyjna koncepcja nauki, krytyka nauki

\section{Science as the sole source of knowledge?} The social advancement of ecology is today probably only comparable to that of science 100 years ago. It is perhaps even larger, or at least more common. The adjective "ecological" and the adverb "ecologically" are popular today not only in theoretical papers from the field of biology but also psychology, sociology, philosophy and even theology. Moreover, specific practices and specifically tangible agricultural or craft products are adorned with the above-mentioned words. The consequence of this, however, is the ambiguity of the term "ecology" - an averagely educated person usually places in it the content which is completely beyond the framework of ecology treated as one of the biology disciplines (Strzałko i Ostoja-Zagórski 1995, 5). Therefore, it is hardly surprising that many proponents of the traditional concept of science tend to place ecology outside the area of science. However, in this context, the demand for revision of the traditional concept of science also becomes understandable.

The advancement and universality of ecological issues are accompanied by two phenomena that are so characteristic of modern times that they are considered, here and there, as criteria that enable us to talk about post-modernity. The first one is significant disappearance of traditional scientific rigour in ecological literature, while the second one is a progressive loss of social trust in traditional science. At first glance, it seems to be about different phenomena, completely independent of each other. If we take a closer look, they turn out to be mutually conditioned, both in the cause and the effect.

\footnotetext{
"This article was originally published in Polish as Hałaczek, Bernard. 2003. "Wkład ekologii w naukę." Studia Ecologiae et Bioethicae 1: 15-24. The translation of the article into English was financed by the Ministry of Science and Higher Education of the Republic of Poland as part of the activities promoting science - Decision No. 676/P-DUN/2019 of 2 April 2019. Translation made by GROY Translations.
} 
The lack of criticism and precision is a well-known shortcoming in the majority of these ecological publications, which, crossing the narrow field of empirical findings, enter into broad and, consequently, not very clearly delineated areas of global explanations and practical recommendations. The representatives of traditional scientific disciplines do not point them out any content errors or formal ones, such as imprecision of initial questions, the vagueness of key concepts, and inconsistency in reasoning and shallow arguments. However, when they make a negative conclusion "devoid of scientific value", they usually fail to see (or they are not willing to notice) how far in their criticism they are the epigones of the 19th-century, the causal-deterministic concept of science. According to this concept, the only thing of value is knowledge free from subjective admixture. As such knowledge is guaranteed by, subject to verification or falsification, exact - narrowed to strictly defined parts of reality - sciences, therefore only these deserve to be called a "good" source of knowledge about reality.

This "good" source has, after all, been 'infected' in recent decades in various ways. In the eyes of the world's public opinion, Hiroshima and Nagasaki were heavily contaminated by the destructive power of bombs. However, the possibility of developing an atomic bomb had not forced anybody to question the widespread trust in science yet. The main reason was that the evil caused by science was desired one, consciously planned by a human. Thus, science may have still been considered a faithful, although in this case an improperly used tool in human hands (Oppenheimer 1964). The 'infection' of the hitherto clear source of scientific knowledge was definitively proven only when the achievements of science, which had seemed to serve people, began to harm them. Stories concerning DDT, Seveso and Chernobyl as well as problems with radioactive waste, acid rain and ozone holes are just some of the most obvious manifestations of human helplessness towards some of the inventions of science today. This helplessness was the reason for the emergence of a new scientific discipline in the early 1970 s - bioethics (Hałaczek 1994). However, ecology was earlier confronted with the consequences of this helplessness. As a result of the pressure of this confrontation, ecology began to emerge beyond the safe framework of exact empirical science.

People owe scientific knowledge numerous new and constantly increasing possibilities. However, science does not provide any answers to the problems occurring together with these possibilities. The search for solutions is being outsourced to more and more frequently appointed and more specialized ethics committees. These, in turn, cannot - and are usually not willing to - enjoy the privilege of drawing from an "objective" source of scientific knowledge. Monod's "ethics of knowledge," i.e. ethics supported by the scientific objectivity, has gained neither philosophical nor "scientific" approval (Mohr 1991). It did not gain any approval mainly because today it is obvious that there is a multitude of conditions to which all evaluations are subject, and even more, the guidelines concerning "whether and how" to take advantage of the possibilities created by science: they are economically, politically, ideologically and religiously conditioned. However, as they are conditioned in various ways, they are questionable by nature. With the loss of primary trust in science as an instance that is powerful and explaining everything, the need for other ones, correcting the science and complementing the sources of knowledge, is spontaneously increasing.

Pointing out the importance and necessity of knowledge deprived of the authority of modern science can, in the context of all human history and all individual experiences, be considered as care reminiscent of the proverbial pushing at an open door. It stops being that when science itself shows this necessity. Indirectly, it does so through negative effects which it causes in conjunction with technique; directly - through self-critical reflection on the limits of one's own cognitive abilities. The cognitive 
knowledge, which so far had been known as an attribute of objectivity, began (from the mid-twentieth century) to notice more and more admixtures of various subjectivity in its own backyard (largely under the influence of methodological analyses of physical cognition), and consequently, voluntarily give up the status of its short-term uniqueness. The final result of this self-reflection is that two - equally valuable and equally legitimate - sources of knowledge have been clearly mentioned since the 1990s. However, 'science' is still considered to be one of them. The second source is a broad socio-technical context which was not taken into account (or was shamefully hidden) by science earlier (Gibbons et al. 1994; Nowotny 1999).

The issue of social conditions of science was ignored in the past for two reasons and in two different ways. The first one was the division of sciences into "pure" (basic, theoretical), whereas the second one was the belief in axiological neutrality of the former. Science as such - as it was thought and called - deals only with facts, not with values; its statements are to be purely descriptive, without value judgement. Although it was admitted that science did not have bare facts either, i.e. each time the facts were interpreted somehow, the interpretative function was more closely connected with one or another theory than with people who created such theories. It was only Thomas Kuhn who dared to talk clearly about specifically human, thus subjective, conditions of scientific theories. A. Paul Feyerabend extremely described the level of this subjectivity in the slogan: "anything goes," an appropriate one, according to him, because "the truth is (only) what in a certain style of thinking is considered to be true" (Feyerabend 1984, 77).

The criticism of such a cognitive approach, significant for the entire literature and philosophy of postmodernism, emphasises almost exclusively its socially destructive influence: that it promotes individualism of values and relativism of truth. That is why, perhaps, the paradoxical merit of this approach eludes attention, namely the one consisting in the appreciation of a human factor of "scientific" cognition, the criticism of a man with regards to the confidence and correctness of this cognition has increased. This, in turn, allowed observing, more clearly than ever before, the relationship between scientific research and human expectations and values. The associated social threats have resulted in a debate in an ecological environment on the correctness of human relations to the natural environment and the critical assessment of the dominant so far anthropocentrism.

\section{The role of ecology in the criticism of the traditional concept of science}

Ecology is considered, since its isolation as a specific biological discipline, as the one giving away the "scientific character" to many other disciplines. This is probably because this research mainly focuses on relationships, meaning unstable relationships, subject to temporal and territorial variability. As such, they escape presentation, in the form of unambiguous descriptions and deterministic explanations, and they therefore hardly fit the requirements of the classical scientific disciplines. This requirement is not met by ecology, if only because it has to take into account the volitional human activity. And in an entirely clear way, it does not meet that while proceeding from questions like "how is it?" to "how it should be", so it begins to seek and give normative-evaluative answers. Its status as a separate scientific discipline is supported, in this case, almost exclusively by the indisputable fact that its research is a compact set of real and specific problems. This criterion means that a negation or an affirmation of the scientific character of ecology must lead to two different conclusions regarding science itself: either to acknowledge that the cognitive aspects of science do not apply to the whole reality or to revise the traditional understanding of scientific cognition.

The proposals to review the traditional understanding of science are dominated nowadays by the desire to broaden its scope to include the contemporary ecological problem, which faces, so far, an uncritical 
excess of emotionality and moralism (Hull 1999, 80). The content direction of such a revision of science was shown and postulated as early as in 1991 by Vittorio Hösle, when he concluded his philosophical analysis of the ecological crisis with a statement: "the need of the moment is not abolishment but the transformation of science. Science should become more global, more entirety-oriented; it cannot be narrowed to one subject only, moreover denying it any signs of subjectivity. Its new causality method of cognition must be subordinated to the concept of cognition of the essence, and the concept should be guided by the idea of the good" (Hösle 1991).

Undoubtedly, the idea of good is present nowadays, in all that is being done under the banner of the broadly-understood ecology. "The concept of ecology - as stated by Jan Strzałko and Janusz Ostoja-Zagórski - gained a notable meaning for most users of the term 'ecological' meaning good, 'non-ecological' - bad...' (Strzałko i Ostoja-Zagórski 1995, 5). However, is it necessary to close this statement, as those listed biologists do, with a conclusion that ecology, understood in this particular way, has little in common with ecology - the discipline of biological sciences? In the critical evaluation of the traditional understanding of science, a conclusion is also acceptable, that there is a need to perceive the valuating elements within all scientific disciplines, however strongly distancing so far from the value categories.

The belief that scientific knowledge is non-evaluative is methodologically correct and worthy of affirmation when its incompetence in the field of ethics is certified and when it reminds us that the structure of science does not have a mechanism to guarantee the ability to determine the criterion of morality. This belief is clearly wrong while looking at science from the perspective of its internal relationship with technology. It already becomes wrong when the scientific cognition gains a rank of exclusively justifiable, meaning best cognition. This is because the process of acquiring scientific knowledge is invaded by a decision of a valuable nature subjecting "legitimate knowledge" to all other values. Even if scientific knowledge is not claimed to be the primary value, it undoubtedly is a value of human existence. The existence which, apart from the value of knowledge, needs and knows many other values.

Ecology is, for at least two reasons, made more sensitive, than many other scientific disciplines, to the impossibility of full elimination of a valuable factor from the field of its research. The first reason is the subject of its research, as already mentioned: at the background of every statement of a fact of one relationship or another, meaning at the background of every answer to "how is it?" there is a question lurking "how could it be?". And where there is an option of a possibility while making a choice, some concept of duty always appears, thus a category of values is involved in the description of facts. The second reason for the fluidity between facts and values recorded exceptionally well in the ecology field is progressive disappearance of the boundary between nature and culture, namely between things created by nature and those created by a man. And since the component of a specific human action is always, in any case, a structured range of values, therefore a man spontaneously "measures" the whole environmental relation with this scale. One makes it more intense and more often, the more difficult it is to distinguish between the "artificial" and the "natural" relations, the more often coincidences of both relations form - as, for instance, in the genetic technology - a compact whole (Nowotny 1999, 63-64).

It is quite obvious for the value issue to be present in the field of those terms which are usually used to justify the necessity, however debatable, to abstract an ecology of a man. Within its framework, the importance of value is imposed even without the above-mentioned reflection on the subject and content of ecological relations. It also imposes, without justified in the context of those relations, a necessity to emphasise the importance of the "inner environment" and its protection against a "contamination" of 
values humiliating a man. After all, no one denies the fact that the quality of human actions and behaviour depend on the defined, more or less consciously, visions of values. That is why even the Coryphaeuses of sociobiology discuss this dependency a lot, and although they explain its appearance as a coincidence, they see it as an inalienable component of human thinking and action (Wilson 1998). And awarded in 1981 with the Nobel Prize in medicine, a neurophysiologist Roger Sperry, is convinced that the ability to value is an integral part of brain processes, and as such, they decisively shape the causal mechanism of human decisions. Therefore, he has been advocating for many years to impose a belief of the subjective nature of values, for instance, because of the direct link between environmental risks and evaluating human judgements (Sperry 1983; Hałaczek 1996).

However, the ecology of a man is confronted with the problem of value not only based on evaluative human equipment. The component of a value is also present there, because the results of the human-environment relationship are real losses or gains of one of the members of that relation, and thus something that implies and results in evaluative judgements. And such evaluations are indispensable, both when describing current human-environmental relations, on the horizontal level, and also on the vertical level, that is while trying to explain human development by lesions those relations in the past. In the latter case, the point is that a naturalist cannot explain the phylogenetic development of a man in any other way but by changing the relation of a man to an environment: either by adapting a man to the requirements of a new environment or by the ability of a man to create his own adapted environment. For instance, by the disappearance of lush subtropical vegetation, a reduction in the size of tusks, the beginnings of two-footed locomotion, an increase of a brain, efficiency of collective hunting, an ability to cook vegetable and meat dishes is explained ${ }^{1}$. On a directly

${ }^{1}$ The subtitle of the most recent dissertation on the accessible horizontal level, the change in human relations to the environment is dictated by the ecological crisis. Its outcomes force a man to re-evaluate the nature and recognise its intrinsic value, and consequently to demand that the economic growth does not take place- as it is described by of the reports of the Club of Rome - "on the account of nature" (Dieren 1995). In turn, the appreciation of nature leads to a deeper reflection on the specificity of human values and a belief in global harmfulness of consumer behaviours (Michelsen und Siebert 1985, 27).

\section{Specific "scientific character" of ecology}

For the further course of this study, it would be very useful to know the birth and development of trends or intellectual phenomena that are so different in their content, what they are nowadays: the common awareness of ecological threats, the revised concept of modern science and a distinctive for a contemporary philosophy pluralism (or post-modern) and relativism of truth. Such knowledge would require separate historical analyses. After all, the well-known difficulty of a temporal location of any beginnings, in particular thought processes, excludes the possibility of obtaining precise findings in this matter. It seems likely, that the result of such analyses would consider the philosophical relativism of truth and a methodological criticism of science, if not as a foundation, then in any case as a historical neighbour of a problem known today as ecological.

Thus, the historical context itself of the birth of ecology and the formation of ecological consciousness to some extent justifies, and makes it understandable, that this newly emerging discipline of knowledge will not be, and will not be influenced by the classical, mainly in the area of physics, established criteria of controllability, authenticity, scientific character. Multiple shortcomings and inaccuracies of those criteria are well-known in the field of modern

causes of human origin is very meaningful: "Cooking and ecology of the origins of humanity" (Wrangham et al. 1999). 
methodology of science and are critically discussed in its context (Kamiński 1992, 11-32 and 284-320). It seems, however, that the awareness of this discussion is not too common among environmentalists. This probably partly explains, the quite persistent effort of many ecologists, to make their discipline "scientific", that is to locate within the traditional concept of science not only biological ecology but also conclusions in the field of psychological ecology or ethical-philosophical ecology (Pfordten 1996; Willi 1996; Eliasz 1993). No one should, of course, be prevented from trying to redefine ecology as a self-taught science in the traditional way, for instance by establishing its material and formal subject matter, its place within the circle of other sciences, or by searching for a theory covering the whole range of ecological statements and methods allowing them to be verified or falsified. Such efforts might be a valuable methodological play, but they are of little significance to ecology itself. A relevant and prime question should be, how to solve the well - known and existing ecological problems, and only secondary and incidentally, should we care about the scientific status of this discipline which aims at solving those problems. At the same time, it is worth to constantly remember that science is only one of a man's creations and tools. It must be remembered because the human subjectivity was repeatedly diminished in the past, or even denied, in the name of science considered as the only impartial, independent from human subjectivity source of truth and knowledge.

No other scientific discipline has ever been forced to giving such an emphasis on the role of human subjectivity, as it must be done nowadays by science. And it has to do it because of two different, though closely related, reasons. Firstly, because a man becomes familiar with environmental problems during, and thanks to, a confrontation with the environment where he lives, which is his environment. Secondly, because in the field of ecological problematics, what a man personally experiences becomes the truth, and the truth is what the man is per- sonally convinced to be true. More simply and concisely: ecological knowledge is the result of participatory observation, and ecological truth has a nature of involving truth. In this way, a subjectivity, which the traditional concept of scientific knowledge and scientific truth has been trying to eliminate, is a component of good knowledge and correct truth in ecology.

The subjective content of truth and ecological knowledge does not identify with, however, its indiscriminate freedom. On the formal side, it is fully subject to, what Krzysztof Łastowski calls, the requirements of the methodological standard. These requirements include, among other things, a clear definition of initial assumptions, a precise definition of used terms and nature of connections between those terms (Lastowski 1999). However, the criticism which is postulated and required in the ecological literature does not mean concealing, or the less negating, subjective contents, but on noticing them and showing their importance or indispensability in solving ecological problems.

The knowledge-making role and merit of ecology results primarily from its need to take into account and validate a subjective - human cognition. This contribution of ecology into the edifice of knowledge, which, by emphasizing the importance of environmental relations has enriched other disciplines (for example medicine, psychology or sociology), is similar, for instance, to what chemistry does to physics or geology. An entirely peculiar contribution of ecology, on the other hand, is the awareness of the awkwardness and inadequacy of classical scientific knowledge while solving many, mainly ecological, problems of modern times. Contrary to past beliefs, for instance, it is not science that decides nowadays of what is, and what is not progress, it does not separate the acceptable from the enforceable, and it is not able to protect a man from taking dire risks. An indicator and a meter in this type of problem is a man himself with his whole range of rational cognition, not bound to a single, predetermined slice of reality. 
Thus, in the form of a somewhat simplified summary, one can speak of two merits of ecology. The first one is direct and generally quite well known. It means that, in case (that is a perspective) of the ecological crisis, it demands from a man, different than so far, a more caring attitude towards nature. The second merit may be called indirect, although in its momentous nature it is not inferior to the first one, or is perhaps even above it because it radically changes the dominance of scientific cognition which is a couple of centuries old and yet not very critical. Its main focus is the encouragement towards science, to give up its role of an omniscient teacher, and proceed from its triumphant teaching to the humility of a student, who also appreciates other types of cognition.

\section{Bibliography}

Dieren, Wouter Van. 1995. Taking Nature into Account. A Report to the Club of Rome: Toward a Sustainable National Income. New York: Copernicus.

Eliasz, Andrzej. 1993. Psychologia ekologiczna. Warszawa: Wydawnictwo Instytutu Psychologii Polskiej Akademii Nauk.

Feyerabend, Paul. 1984. Wissenschaft als Kunst. Frankfurt a. M.: Suhrkamp.

Gibbons, Michael, Camille Limoges, Helga Nowotny, Simon Schartzmann, Peter Scott, Martin Trow, Roger Gomm, Martyn Hammersley, and Peter Foster. 1994. The New Production of Knowledge. The Dynamics of Science and Research in Contemporary Societies. London: Sage.

Hałaczek, Bernard. 1994. „Co ekologię z bioetyką łączy..." Studia Philosophiae Christianae 30(2): 135-150.

Hałaczek, Bernard. 1996. „Obiektywizm subiektywności w mentalizmie Rogera Sperry." Studia Philosophiae Christianae 32(1): 267-270.

Hösle, Vittorio. 1991. Philosophie der ökologischen Krise: Moskauer Vorträge. Munchen: Beck.
Hull, Zbigniew. 1999. „Problemy filozofii ekologii.” W Wprowadzenie do filozoficznych problemów ekologii, red. Andrzej Papuziński, 55-95. Bydgoszcz: Wyższa Szkoła Pedagogiczna.

Kamiński, Stanisław. 1992. Nauka i metoda. Pojęcie nauki i klasyfikacja nauk. Lublin: Towarzystwo Naukowe Katolickiego Uniwersytetu Lubelskiego.

Łastowski, Krzysztof. 1999. „Ekologia a filozofia." W Wprowadzenie do filozoficznych problemów ekologii, red. Andrzej Papuziński, 1153. Bydgoszcz: Wyższa Szkoła Pedagogiczna.

Michelsen, Gerd, und Horst Siebert. 1985. Ökologie lernen: Anleitung zu einem veränderten Umgang mit Natur. Frankfurt a. M.: Fischer-Taschenbuch-Verlag.

Mohr, Hans. 1991. "Homo investigans und die Ethik der Wissenschaft." In Wissenschaft und Ethik, Hrsg. Hans Lenk, 76-94. Stuttgart: Reclam Verlag.

Nowotny, Helga. 1999. Es ist so-es könnte auch anders sein: über das veränderte Verhältnis von Wissenschaft und Gesellschaft. Frankfurt a. M.: Suhrkamp.

Oppenheimer, Robert J. 1964. The Flying Trapeze - Three Crises for Physicists. London: Oxford University Press.

Pfordten, Dietmar von der. 1996. Ökologische Ethik: zur Rechtfertigung. Reinbek bei Hamburg: Rowohlts Taschenbuch Verlag.

Sperry, Roger W. 1983. Science and Moral Priority. Merging Mind, Brain, and Human Values. New York: Praeger.

Strzałko, Jan, i Janusz Ostoja-Zagórski. 1995. Ekologia populacji ludzkich. Środowisko człowieka w pradziejach. Poznań: Wydawnictwo Naukowe UAM.

Willi, Jürg. 1996. Ökologische Psychotherapie. Göttingen: Hogrefe.

Wilson Edward O. 1998. Consilience. The Unity of Science. New York: Knopf.

Wrangham Richard W., James H. Jones, Greg Laden, David Pilbeam, and Nancy L. Conclin-Britiain. 1999. "The Raw and the Stolen: Cooking and the Ecology of Human Origins." Current Anthropology 40(5): 567-594. 